Lins, S., Marques, M., \& Aquino, S. D. (2021). "What drives one to buy on impulse?" A qualitative study with a Portuguese sample. Consumer Behavior Review, 5(1), $17-30$

ISSN: 2526-7884

Editor: Prof. Dr. Marconi Freitas da Costa Evaluation: Double blind review Received: March 26, 2020

E-mail: cbr@ufpe.br

Accepted: October 14, 2020

\title{
“WHAT DRIVES ONE TO BUY ON IMPULSE?” A QUALITATIVE STUDY WITH A PORTUGUESE SAMPLE
}

“O que te leva a comprar por impulso?" Um estudo qualitativo com uma amostra Portuguesa

\author{
Samuel Lins ${ }^{1}$ \\ ORCID: http://orcid.org/0000-0001-6824-4691 \\ E-mail: samuellins@fpce.up.pt \\ Maria Marques ${ }^{1}$ \\ ORCID: https://orcid.org/0000-0003-3616-8692 \\ E-mail: mariainesmarques_96@hotmail.com \\ Sibele Aquino ${ }^{2}$ \\ ORCID: http://orcid.org/0000-0003-1391-0911 \\ E-mail: sibele.aquino@gmail.com
}

${ }^{1}$ Universidade do Porto, Porto, Portugal

${ }^{2}$ Pontifícia Universidade Católica do Rio de Janeiro, Rio de Janeiro, Brasil

\begin{abstract}
The present study aimed to identify the main factors that lead people to buy impulsively. 925 Portuguese participated, with an average age of 27.02 years $(S D=10.73)$, who answered a questionnaire online. Participants were asked to answer the question "What makes you buy on impulse?" The data were analysed through content analysis, and the responses were grouped into seven categories: (1)
\end{abstract}

\begin{abstract}
Resumo
0 presente estudo teve como objetivo identificar os principais fatores que levam as pessoas a comprar impulsivamente. Participaram 925 Portugueses, com média de idade de 27.02 anos (DP $=10.73$ ), que responderam a um questionário numa plataforma online. Foi solicitado aos participantes que respondessem à questão " $O$ que te leva a comprar por impulso?". Os dados
\end{abstract}


Internal factors, (2) Monetary value, (3) Product characteristics, (4) Situational factors, (5) Type of products, (6) Early involvement, and (7) Social value. Internal factors and Monetary value were highlighted as the main factors that lead to impulse buying. The results showed consistency with previous studies.

Keywords: Impulse buying, Consumer behavior, Buying intention. foram analisados por meio da análise de conteúdo, e as respostas foram agrupadas em sete categorias: (1) Fatores internos, (2) Valor monetário, (3) Características dos produtos, (4) Fatores situacionais, (5) Tipo de produtos, (6) Envolvimento antecipado, e (7) Valor social. Os Fatores internos e o Valor monetário foram destacados como os principais fatores que levam à compra por impulso. Os resultados revelaram consistência com estudos anteriores.

Palavras-Chave: Compra por impulso, Comportamento do consumidor, Intenção de compra.

\section{INTRODUCTION}

There is a relevant focus on impulse buying among studies on consumer behavior, which occurs when consumers are motivated to urgently satisfy some need (Akyuz, 2018). After making a purchase, impulsive consumers experience emotional, cognitive, and behavioral reactions, which become a new motivation that can trigger repetitive impulse buying behaviors (Ko, 2018).

Considering that in impulse buying information processing is limited, consumers are usually involved in simplified decision-making processes. In this way, an impulsive purchase can be based on a heuristic, even if a product provokes, or not, some level of enthusiasm, joy, and willingness to buy (Sato \& Verplanken, 2011).

Over the years, research on consumer behavior has revealed that various stimuli have strong, and often irresistible, influences on consumers' purchasing decisions, even without their knowledge (Hu, Li, \& Liu, 2013). In this sense, the present study aims to identify factors that lead people to buy impulsively. It is essential to highlight that most studies on impulse buying have been presenting quantitative methodologies. However, this article uses a qualitative methodology.

\section{THEORETICAL FRAMEWORK}

\section{Impulse buying}

For Rook (1987), impulse buying occurs when a consumer experiences a sudden, powerful, and persistent desire to buy something at the moment, even though such an impulse may stimulate emotional conflicts. Purchasing impulses are often intense and urgent, and impulse buying is a quick and more emotional than rational experience, more spontaneous than cautious (Rook, 1987).

Impulse buying is seen as an attractive, hedonically complex and unplanned purchase (Stern, 1962). It is described as more exciting, less deliberate, and more irresistible buying behavior than planned buying behavior (Kacen \& Lee, 2002). However, it is necessary to distinguish impulse buying from unplanned buying, often considered synonymous (Stern, 1962). The unplanned purchase, being described as any purchase that a consumer makes, which has just not been conceived in advance (Stern, 1962).

Thus, purchases may not be planned, and at the same time may not be impulsive. Unplanned, non-impulsive purchases are like regular purchases - which unexpectedly solve a pre-existing problem and can be purchased that are merely unimportant to plan or reflect on in advance. On the other hand, impulsive purchases can also be planned, such as, for example, buying a gift for someone (Sato \& Verplanken, 2011). It occurs when the consumer decides to buy something they already wanted but did not think to buy precisely at that time. That said, impulse buying generally unplanned arises from 
stimuli to which the consumer is exposed, however, a purchase can be planned in advance, but the consumer does not expect to buy at the moment it occurs.

As consumers go shopping, they are exposed to stimuli that encourage them and drive them to buy products, giving in to the act of impulsively buying the product, even if they are not sure whether or not it will satisfy any need, or whether the purchase will trigger a positive or negative consequence on them (Khawaja, 2018). Similarly, technologies, television shopping channels, and the internet represent incentives for impulse buying opportunities on the part of consumers, increasing access to products and services by providing simplified and immediate ways in which these purchases can be made (Kacen \& Lee, 2002).

\section{Factors that influence impulse buying}

Different stimuli lead to impulse buying. They can be related to the consumer's characteristics, the buying environment, the product itself, the socio-cultural aspects (Bhakat \& Muruganantham, 2013), social factors, sales promotions, advertising, the shop environment, the socio-demographic characteristics (Ambreen, Bushra \& Zulfiqar, 2018), economic factors, or even the time dedicated to shopping (Stern, 1962).

Variables such as available time and money - in addition to individual variables such as pleasure in shopping and the tendency to buy on impulse - influence other variables, such as positive and negative effects, and the need to buy impulsively (Beatty \& Ferrell, 1998). Personal available income, lifestyle, and credit availability are also factors that make impulse buying more probable (Ambreen et al., 2018).

Still, impulse purchases may act to affirm or express an aspect of a person's identity, considering that the products serve purposes that are not just utilitarian or hedonistic (Sato \& Verplanken, 2011). In this way, the purchased products may symbolize both a current or an aspired lifestyle and social groups, classes, values, religion, regional identities, and even political positions (Sato \& Verplanken, 2011). Next, four factors influencing impulsive buying will be presented: (1) Economic factors; (2) Product-related factors; (3) Situational factors; and (4) Internal factors.

\section{Economic Factors}

Financial availability has a direct impact on the desire to buy impulsively (Badgaiyan \& Verma, 2015). In this case, the use of credit cards is seen as the most effective way to buy (Raheem \& Vishnu, 2013), as consumers do not pay instantly, which makes it likely that they will spend more they buy impulsively (Akyuz, 2018). Credit cards encourage consumers to visit shops frequently, which can increase impulsive shopping (Aquino, Natividade \& Lins, 2019; Muruganantham \& Bhakat, 2013).

It is also necessary to consider the monetary value of purchases as an economic factor that predicts impulse buying. The monetary value concerns discounts, promotions, and unexpectedly lower prices, which influence most consumers and lead to impulse buying (Raheem \& Vishnu, 2013). Promotions encourage consumers to make an immediate decision, increasing the sudden interest in the products, converting them into real purchases, and increasing the probability of impulse buying behavior (Akyuz, 2018).

\section{Product Related Factors}

Consumers often make spontaneously and intuitively unplanned purchases after being exposed to stimuli such as the characteristics of the product itself: exclusivity, attractive appearance (Hu et al., 2013) - such as size, durability, color or packaging -, the brand, the quality, the novelty, the utilitarianism.

Concerning the aesthetic value of the product's design, this is defined as the consumer's perception of attractiveness and pleasure arising from the appearance of the product. The aesthetic properties are mostly hedonic, as the product's design is more than a good appearance or functionality; it is about satisfying consumers' wishes at various levels (Kumar \& Noble, 2016). On the other hand, unlike hedonic behavior, marked by pleasure, in utilitarian behavior, consumers look for functional benefits and economic value in the purchase process (Bhakat \& Muruganantham, 2013). 
The functional value of a product design is defined as how it helps to meet the consumer's practical or utilitarian needs (Kumar \& Noble, 2016).

Also, the exclusive availability of a given product increases the probability of buying on impulse (Bhakat \& Muruganantham, 2013). An item with a short shelf life is subject to being purchased more often than a product with a longer shelf life, apart from consumer needs that may be transitory. Even so, the shorter the cycle of the life of an item, the more likely it is to be purchased on impulse (Stern, 1962).

Also, the product's perceived quality means any aspect of a product (Dorfman \& Steiner, 1954) that meets the consumer's needs. The choice of a product to satisfy particular needs depends on the consumer's perception of how much the product's quality is capable of satisfying those needs, that is, the quality of the product requires an understanding of what consumers expect. Furthermore, quality itself is important, but equally relevant is the right color of the product, its weight, or its size (Agyeiwaa, Agyekum, \& Haifeng, 2015). This perception varies from to consumer.

Associated with quality, often appears the product's brand. The brand can increase the perceived usefulness of the product and make it more desired (Ferla, 2009). The brand is attributed with intangible characteristics, values, feelings, ideas, or affections, which overestimate even the relationship with the product and its functional performance (Ferreira, 2013). It conveys familiarity, reliability, and security to the consumer. Its power and value are instilled in consumers by increasing their self-esteem and status through purchase (Herbig \& Palumbo, 2000). Consumers buy certain brands to reinforce their participation in a specific global segment (Alden, Batra \& Steenkamp, 1999).

Similar to the characteristics mentioned above, novelty increases impulse buying, taking into account that consumers actively seek novelty, knowledge and inspiration (Hall \& Towers, 2017), and trying out new products may offer consumers opportunities to explore new alternatives and vary their choices outside of the already known stimuli (Hirschman, 1980). Still, the new product may involve risks in dealing with uncertainty (Schiffman, 1972). The search for new products is described as the search for variations of already known stimuli. Therefore, their change may reduce boredom or fatigue (Hirschman, 1980) - which is one of the regulatory functions of impulse buying.

Finally, as to the type of product, a given product that is positively related to consumers is more likely to be purchased on impulse (Chen, 2008), since consumers seek through it to increase their self-esteem and their social respect (Hor-Meyll, Livramento \& Pessôa, 2013). Any trip to a shopping center exposes the consumer to a range of products and stimuli, making it difficult to escape the need to buy, especially for people with a strong impulse or too involved with the products (Chen, 2008).

\section{Situational Factors}

Situational factors that influence an impulsive purchase may be related to the time and opportunity to purchase or may result from situations in the shop, such as shop environment and display. These factors are circumstantial variables that can change with time and occasion, depending on the consumer's will.

Impulse buying can be related to real or perceived available time (Beatty \& Ferrell, 1998; Badgaiyan \& Verma, 2015), or to the opportunity to buy a product, which is characterized by product availability (being rare or limited) and the fact that the consumer considers this product essential and/or pleasant. The desire to buy can naturally increase when the products are rare or exclusive (Christopher, Marek \& Troisi, 2006).

In view of the factor resulting from the situation in the shop, it comprises the shop environment, which includes its atmosphere and the display of products. Thus, the display of products in the shop influences impulse buying, requiring a high display of these items to increase the probability of impulsive purchase, therefore, the display includes special promotions, differentiated packaging, and a favorable position on the shelf (Stern, 1962) showing product availability through visual and organized presentation (Raheem \& Vishnu, 2013). Besides, a clean environment, spacious formats, and the shop's size increase this type of purchase (Bhakat \& Muruganantham, 2013). 
In this sense, the shop's internal environment and its physical appearance influence consumers' decision to select the shop they will buy (Underwood, 2003). Ambient music, the display of goods and services, a well-trained team, cleanliness, ample space, lighting, layout, colors, and odors also play a significant role in impulsive shopping (Bhakat \& Muruganantham, 2013; Raheem \& Vishnu, 2013). Thus, the shop's image, the pleasant environment, and the various stimulating elements create a shopping environment that awakens the senses, attracts attention to specific products, and causes positive emotional states (Herabadi, Knippenberg \& Verplanken, 2009).

Finally, the display, which can be differentiated in familiarity and advertising. Much of the impulse purchase consists of a high level of the consumer's knowledge about the item obtained from previous experience with the product or advertising (Stern, 1962). Consumers may have different expertise or familiarity with the product due to their individual experience with it, which will have a different impact on the consumer's evaluation of the product. However, consumers who have no previous experience have limited information when evaluating the product's attributes and alternatives (Lee \& Yu, 2018). In advertising, however, and although its objective is to create planned purchases, its incentive as a reminder assumes great importance as the incidence of impulse purchases increases (Stern, 1962).

\section{Internal Factors}

Finally, internal stimuli are related to the different factors that characterize an individual and not to the environment or stimulus of purchases. These impulse buying factors show the individual's internal traits and characteristics that involve him in impulse buying (Bhakat \& Muruganantham, 2013). For example, product involvement is considered an individual differential variable, causal, or motivational, influencing consumers' buying behavior (Kapferer \& Laurent, 1985). When the involvement is high, the product is seen as necessary in the context of primary motivations and felt needs (Popadiuk, 1993).

Involvement is also understood as the perceived importance of the product, or just the interest in a specific category of products, even if it contains the affective and utilitarian components (Popadiuk, 1993). However, early involvement involves extra variables such as time spent searching for the product or the number of visited shops (Popadiuk, 1993). In the literature, involvement is also described as the perception of the importance of the product, the perception of the symbolic value, the perception of the value of pleasure and the perception of risk (Kapferer \& Laurent, 1985).

On an emotional level, individual states such as anxiety, being stressed or bored, as well as hedonic motivations are important internal sources of impulse buying that result in product-driven enthusiasm, leading to specific beliefs about the consumption (Blut et al., 2019). Instant gratification is an internal hedonic need that stems from personal experiences' positive behavioral consequences (Ko, 2018). Consumers may believe that objects' purchase will provide emotional gratification, compensation, or minimize their negative feelings (Blut et al., 2019).

Regarding the cognitive level, curiosity, the illusion of the need for a product and the lack of control have an impact on impulse buying. Self-control can consist of actions such as thinking about not spending money or not being close to shop windows, however, the task of exercising self-control may fail (Sato \& Verplanken, 2011). This way, impulse buying occurs when one desires to obtain the product or when there are failures in controlling that desire (Coley, 2002).

Finally, in volition, consumers generally face the desire to buy products that are not on their shopping lists, and this temptation leads them to make impulsive purchases (Akram, Hashim, Hui, Khan, \& Saduzai, 2016). The planned decision to buy for self-satisfaction and the temptation to buy desired products are two factors that influence consumers to buy impulsively (Akram et al., 2016). Here, normative evaluation and instant gratification significantly influence the desire to buy impulsively (Hu et al., 2013).

The normative assessment can be established through social value associated with status, external opinion and social compliance. The acquisition of material goods is one of the most decisive measures of social success and achievement ( $0^{\prime}$ Cass \& McEwen, 2004). The social value represents how a person can use their goods to reinforce their own identity - which depends on social categories 
and which determines, in part, items purchased impulsively (Beattie et al., 1995). Large discrepancies in terms of identity lead the individual to compensate themselves through the impulsive purchase of symbols relevant to identity (Beattie et al., 1995).

Buying to obtain status consists of buying products that, in the eyes of the consumer and others, are associated with certain social statutes to stand out. Status consumption is a matter of consumers' desire to gain prestige by purchasing expensive products and brands $\left(0^{\prime}\right.$ Cass \& McEwen, 2004). Indeed, consumers can buy or consume goods and services, regardless of their income or social class level (Eastman, Goldsmith \& Flynn, 1999). Thus, the consumption of products by status can help people search for self-respect and social approval (Eastman et al., 1999). However, buying to obtain status is more than showing wealth. This type of consumption intends to try to increase the prestige in society and the consumer's well-being (Andrade, Assimos, Leite \& Pinto, 2019; O'Cass \& McEwen, 2004).

Additionally, consumers who live under the pressure of time and the increasing number of decisions to be taken daily end up making decisions based only on others' recommendations. Even for decisions of greater involvement, and the influence of others, such as friends and family, in the decision process is extremely important in impulse buying (Hall \& Towers, 2017). Likewise, the tendency to spend more when you are in a group can be considered an indicator of the tendency towards impulsiveness in purchasing (Eberhardt, Lins \& Poeschl, 2016)

Regarding social conformity, an example are the younger generations, whose peer pressure dominates, and there is a strong desire to belong or to fit into a group or social groups. This generation tends to be brand conscious and loyal to those in fashion, their preferences are primarily determined by what they see in the media and what their peers own (Euromonitor International, 2011).

\section{METHOD}

The present study adopts a quantitative approach of a descriptive nature, carried out through a quantitative survey with a convenience sample formed by 925 participants living in Portugal.

\section{Participants}

925 Portuguese (711 women and 213 men) participated in this study, with an average age of 27.02 years $(\min =18$ years, $\max =72$ years; $S D=10.73)$. Regarding the main occupation, 527 participants were declared to be higher education students, 117 declared themselves workers and students, 247 are workers, 23 were unemployed, and 11 were secondary school students. Regarding the level of monthly family income, 58 participants declared receiving up to $€ 500$ per month, 221 participants claimed to receive between € 501 - € 1000 per month, 247 participants said receiving between $€ 1001$ - $€ 1500$ per month, 181 participants declared receiving between $1501 €-€ 2000$ per month, 109 declared to receive between $€ 2001$ - $€ 2500$ per month and 109 participants declared to receive $€ 2501$ or more.

\section{Collection Procedures}

A link to the questionnaire was released via email and social media. Upon clicking, participants were directed to a virtual platform where the questionnaire was made available and where they were asked to answer the following open question "What makes you buy on impulse?" In addition to the question, the participants reported socio-demographic data such as age, monthly family income, gender, and occupation.

\section{Analysis Procedures}

The responses were analysed through content analysis, carried out by three interdependent judges. Content analysis is characterized as a set of communication analysis techniques, whose objective is to obtain indicators (quantitative or not) that allow the inference of knowledge related to the production/reception conditions (inferred variables) of these messages (Bardin, 2011). Using systematic and objective procedures to describe the content of the messages, the content analysis contains 3 phases: (1) pre-analysis (organization of the analysis); (2) exploration of the material 
(message coding and categorization); and (3) treatment of results (inference and interpretation). It should be noted that the technique of content analysis is frequently applied in qualitative research in the field of management (Dellagnelo \& Silva, 2005; Mozzato \& Grzybovski, 2011)

\section{RESULTS}

In total, 1049 responses were obtained, 1025 of which were used, analysed and from which categories and subcategories were extracted. The percentage of use of responses was of $97.7 \%$ ( $\mathrm{f}=$ 1025 ) and the percentage of not used material, that is, responses that were not categorized was $2.3 \%$ $(f=24)$.

Table 1

Content Analysis on What Leads the Portuguese to Buy on Impulse
Categories
Subcategories
Examples

Enthusiasm; very positive mood states; being bored / sad /

Emotional discouraged; excitement; fear of missing the opportunity; satisfaction with the product; appreciation for the product; pleasure; immediate satisfaction

\begin{tabular}{|c|c|c|}
\hline \multirow[t]{3}{*}{$\begin{array}{l}\text { 1. Internal } \\
\text { Factors }\end{array}$} & Volition & $\begin{array}{l}\text { Need / desire of having something new; the will to have } \\
\text { something I liked; to think they are needed; something I need; } \\
\text { desire }\end{array}$ \\
\hline & Physiologic & $\begin{array}{l}\text { Appetite; greediness; go shopping when hungry; if you are } \\
\text { tired of shopping }\end{array}$ \\
\hline & Cognitive & $\begin{array}{l}\text { Lack of control; the illusion of the need for something; } \\
\text { curiosity; not being dedicated to the act of buying }\end{array}$ \\
\hline $\begin{array}{l}\text { 2. Monetary } \\
\text { value }\end{array}$ & - & $\begin{array}{l}\text { Good prices; good promotion; sales on products that I have } \\
\text { wanted for a long time; cheap prices; very good price / quality } \\
\text { ratio; discounts }\end{array}$ \\
\hline \multirow{6}{*}{$\begin{array}{l}\text { 3. Product } \\
\text { characteristics }\end{array}$} & Aesthetics & $\begin{array}{l}\text { Product appearance; product attractiveness; aspect; beauty; } \\
\text { design }\end{array}$ \\
\hline & Quality & Good product quality; some products being very desirable \\
\hline & Novelty & Being new; something new \\
\hline & Utilitarianism & $\begin{array}{l}\text { Being useful; something I use a lot, even if I don't need to; a } \\
\text { product / service that you have to use later }\end{array}$ \\
\hline & Exclusivity & $\begin{array}{l}\text { Something different; unmissable opportunities; unique } \\
\text { character; different; something that is not available } \\
\text { everywhere; rare to find }\end{array}$ \\
\hline & Brand & Good price on a good brand; quality brands \\
\hline \multirow{5}{*}{$\begin{array}{l}\text { 4. Situational } \\
\text { Factors }\end{array}$} & Opportunity & $\begin{array}{l}\text { The rarity of the product; something that is available for a } \\
\text { limited time; the depletion of the article; }\end{array}$ \\
\hline & Display & $\begin{array}{l}\text { Familiarity: Something I usually buy; Product knowledge; } \\
\text { Experience; Advertising: Advertising/Marketing campaign; A } \\
\text { very well thought out ad }\end{array}$ \\
\hline & $\begin{array}{l}\text { Financial } \\
\text { Availability }\end{array}$ & $\begin{array}{l}\text { Availability of income; having money, I buy; having extra } \\
\text { budget }\end{array}$ \\
\hline & Available time & $\begin{array}{l}\text { Some time you would want to buy; availability of dates; lack of } \\
\text { availability; lack of planning, things at the last minute; hurry; } \\
\text { limited time }\end{array}$ \\
\hline & $\begin{array}{l}\text { Shop } \\
\text { environment }\end{array}$ & $\begin{array}{l}\text { Display in shops; good prices on reliable sites; online shopping; } \\
\text { appealing locations; large and organized shop; a good } \\
\text { presentation / display of product }\end{array}$ \\
\hline
\end{tabular}




\begin{tabular}{lcl}
\hline & \multicolumn{1}{c}{ Clothing } & Footwear; shoes and bags; clothes; a nice piece of clothing \\
\cline { 2 - 3 } $\begin{array}{c}\text { 5. Types of } \\
\text { product }\end{array}$ & Food & $\begin{array}{l}\text { Food; chocolates and sweets; wine; bread, I like to try new } \\
\text { types of bread }\end{array}$ \\
\cline { 2 - 3 } & Beauty & Accessories; bijouterie; make-up \\
\hline $\begin{array}{l}\text { 6. Early } \\
\text { involvement }\end{array}$ & - & $\begin{array}{l}\text { Something you really want for some reason; looking for } \\
\text { something for a long time; something I dream of having }\end{array}$ \\
\hline 7. Social value & - & $\begin{array}{l}\text { Fashion: associating certain items of clothing with certain } \\
\text { social statutes, what makes me more willing to buy; something } \\
\text { that is trendy; someone's indication; status; advice }\end{array}$ \\
\hline
\end{tabular}

\section{Internal Factors}

The first category is the largest and includes $32 \%$ of responses $(f=336)$. Internal factors concern emotional states such as the taste for the product and the satisfaction and pleasure involved in the act of purchasing. The category is divided into four subcategories: (1) Emotional ( $f=203)$, refers to the effective part and is related to the feelings in the act of purchasing, ranging from anxiety, sadness, boredom or stress to the sense of immediate satisfaction such as the purchase of a product that you love; (2) Volition ( $\mathrm{f}=107$ ), refers to obtaining the product according to a decision or a deliberate choice, such as the prior need to get the product, the urgency to acquire it, or the desire to own or know it; (3) Physiological ( $\mathrm{f}=13$ ), refers to the physical needs essential to survival, such as feeling hungry when going to the supermarket, or when you are tired of shopping; and (4) Cognitive (f $=13$ ), the cognitive part is related to the planning and decision of the purchase, involving from the lack of control to the illusion of the need for something that is not needed and dedicating attention to the act purchase.

\section{Monetary value}

The second category includes $31.7 \%$ of responses $(f=333$ ) and refers to the product's monetary value, the amount of money spent on purchases. The answers were grouped as: promotions, discounts, sales, prices and the cost-benefit ratio.

\section{Product characteristics}

The third category includes $15.3 \%$ of the responses $(f=160$ ) and refers to the different properties that a product can have, which arouse consumers' interest to buy it on impulse. This category is made up of six subcategories of characteristics: (1) Aesthetics ( $f=57$ ), corresponding to visual characteristics such as the appearance and attractiveness of the product, caused by the beauty of the product, or the first impression of the product; (2) Perceived quality of the product ( $f=42$ ), refers to the consumers' perception of the quality of the item in question, either because it has quality, for having valuing power, that is, for being attractive and offering good quality / price ratio; (3) Novelty $(\mathrm{f}=19)$, when a product offers something new, never consumed or seen before; (4) Utilitarianism ( $f=19$ ), concerns the possibility of a product being useful in everyday life and being considered relevant, it is the feeling that the product can satisfy daily needs and can be used in everyday life; (5) Exclusivity ( $\mathrm{f}=15$ ), understood as something different and unique or rare to find, characterized by unmissable purchase opportunities; and finally, (6) Brand ( $f=8$ ), regarding the product being a recognized brand.

\section{Situational factors}

As for the situational factors, they represent $8.5 \%$ of the answers ( $\mathrm{f}=87$ ). It is a category that relates to the context of the purchase and is divided into five subcategories: (1) Opportunity ( $\mathrm{f}=25)$, portrays an ideal time to make the purchase, the rarity of the product, or the opportunity to buy, otherwise, the product may be lost because it is available for a limited time, or because it can run out; (2) Display ( $\mathrm{f}=20)$, refers to the visibility of the product, which can be either through familiarity $(\mathrm{f}=$ 
12), when it comes to products that the consumers usually buy or articles that they use frequently or by advertising ( $\mathrm{f}=8$ ), when exposure is through communication campaigns, advertisements; (3) Financial availability $(\mathrm{f}=20$ ) associated with economic power, which includes income and money available for the purchase, involving self-knowledge about their comfortable financial situation and the extra availability of resources that leads people to the shopping center. (4) Available time ( $f=12)$, reflects the time available to make the purchase, the deadlines of current promotions, or even the rush while in the purchase environment; and finally, (5) Physical and online shop environment ( $\mathrm{f}=10$ ), this subcategory encompasses specific characteristics of the physical shop environment - whether it is wide, organized, pleasant or if it has inviting color, lighting, temperature, music and service - or the virtual environment, such as trusted sites and the entire platform organization.

\section{Types of products}

The fifth category includes $5.1 \%$ of the answers $(\mathrm{f}=53)$ and are related to the variety of products that can be purchased, divided into four subcategories: $(1)$ Clothing $(f=18)$ (e.g.: accessories, shoes, bags); (2) Food ( $f=17$ ) (e.g., chocolates, food, sweets, drinks); (3) Entertainment ( $f=13$ ) (e.g., technology, books, music and travel); and (4) Beauty ( $\mathrm{f}=5$ ) (e.g., bijouterie, makeup).

\section{Early involvement}

This category, which includes $4.3 \%$ of the responses ( $f=45$ ), is defined by the desire to obtain a product already known, which is associated with the anticipated desire, the planned purchase and the simple feeling of wanting the product for a long time.

\section{Social value}

Finally, the last category addressed includes $1 \%$ of responses $(f=11)$. The social value represents the community's values, the importance attributed to an object due to the reference social group's influence. This category includes external opinion, such as advice from a friend or someone else's recommendation; the social conformity of wanting to be in fashion or to follow a trend; and the status (e.g., certain items of clothing are associated with certain desirable social statuses, which may make you want to buy more).

\section{DISCUSSION}

This study aimed to identify factors that lead consumers to buy impulsively. A literature review found that several factors influence impulse buying, and the present study has shown consistency with previous studies. That said, and after reading the results, it was possible to verify that the factors that obtained the greatest number of responses were the internal factors and the monetary value of the product.

Most of the responses obtained mentioned internal factors. This indicates that consumers experience emotional, cognitive and behavioral reactions after the purchase, which, consequently, increases the probability of triggering repetitive impulse buying behaviors (Ko, 2018). Internal variables play an essential role in the variation of impulse buying, and this list includes motivations, mood, and the likelihood that the consumer will feel out of control when buying impulsively (Rook, 1987). Likewise, the will, desire and need to obtain a product increase impulsive behavior in purchases.

Within the internal factors' category, the emotional factor subcategory obtained a greater number of notes from respondents, probably because impulse buying is essentially more emotional than rational. It shows that consumers believe that the purchase will provide emotional gratification or minimize their negative feelings (Blut et al., 2019). Thus, impulse buying is seen emotionally as part of an adventure, in order to make one feel better or get relief, providing the feeling of a unique or exclusive opportunity to obtain a product.

The second-largest category cited was monetary value. A large number of responses in this category demonstrates that promotions and discounts are considered by consumers as a driving factor for purchases. For this reason, low prices are a reason for impulse buying, mostly when related to 
quality-price. When there is prior consumer involvement with the product and unexpectedly becomes cheaper, consumers are also highly likely to buy on impulse. In this way, attractive pricing strategies and promotions in shops increase consumers' involvement and drive them to make more purchases (Atulkar \& Kesari, 2017).

The products' characteristics was another category that obtained a high number of responses, and in this category are the quotes that point out the properties of the products as stimuli that arouse purchase desires, even though the product is not an urgent need. The fact that this category is less mentioned than those previously presented may indicate that the properties of the products are subjective and, therefore, perceived differently by consumers.

In this category, aesthetics was the subcategory most mentioned by participants, indicating colour, shape or even texture as necessary in impulse buying (Stern, 1962), which suggests that consumers tend to buy more impulsively products that are visual and aesthetically pleasing. As the exclusivity of products increases the impulsiveness in purchasing, so does the quality of these matters, and depending on the consumers' perception of the quality of a product, they can be purchased more or less impulsively. In this way, some consumers perceive that a product has high quality if it has a high price, others determine the quality based on the country of origin, taste, smell, size, or packaging (Agyeiwaa et al., 2015).

Still, on the product's characteristic, the quote about the brand stands out. The brand is an entity built to seduce (Campos \& Sousa, 2011). It refers to a name, sign, symbol or design used to differentiate its offers from those of its competitors (Herbig \& Palumbo, 2000), to create a relationship with the customer, which leads to a greater impulsive purchase. It may be understood as previous involvement with the product since the consumer needs to know it before having access to it in the shop, deciding to buy the product based solely on the brand it represents. The novelty is considered a strategy that leads to impulse buying, considering that innovative trends in the design of new products make consumers look for innovation: products launched with a different design leave the usual shelf item for mandatory items.

Similarly, the utility or functionality that a product has in an individual's daily life drives the item's impulse buying. The functionality of items that can be applied to everyday life with a specific function is seen as driving impulse buying. This way, the more beautiful, unique, useful and rare/exclusive a product is, the greater the desire to buy it impulsively.

The categories with the least mentioned responses were situational factors, type of product and early involvement. In situational factors, the shopping environment's characteristics include stimuli within the shop that influence both, directly and indirectly, the consumer (Bhakat \& Muruganantham, 2013). Therefore, consumers may not perceive the direct influence of this factor. For example, in the context of sales, consumers prefer shops with which they are emotionally connected, which generate positive feelings in the buying process, which leads to impulse buying (Atulkar \& Kesari, 2017). Retailers must therefore invest in a shop environment where negative perceptions are reduced, promoting impulse buying as a response to strong positive emotions generated by shops (Atulkar \& Kesari, 2017; Gutierrez, 2004).

As shop environments are highly competitive, only salespeople who exceed their customers' expectations, and ensure a pleasant shopping experience, persist in the activity and become a success (Gutierrez, 2004). Thus, good salespeople increase their perception of the overall quality of the shopping experience, seeking to improve the variety of products offered. The shopping environment satisfies the hedonic demand of customers, triggering impulse purchases (Gutierrez, 2004). Bearing in mind that shops and sellers are experiencing a trend around the world because, with the change in consumer's choice, taste and standards, shops try to sustain and sell their products by keeping "strong the strategic aspects of their marketing activities" (Raheem \& Vishnu, 2013).

Even if the consumer is in a pleasant environment, with exposure to products that attract them by whatever the characteristic, an impulse purchase is less evident if they do not have time to perceive the stimuli and indulge in impulsive behavior in purchases. People who have more commitments to fulfill and less time available to be in commercial environments will tend to be less exposed to products and buy less on impulse. 
Financial availability should be sparingly highlighted. While having the resources available to buy is essential to carry out any commercial transaction, currently, the use of credit cards instead of physical money can foster a false impression of availability, making consumers not remember that this is a category that directly impacts their purchasing decisions. For example, the use of credit cards makes it possible to spend without worrying about the existing balance, acting as an incentive for extra purchases (Bhakat \& Muruganantham, 2013). This data does not seem to be one of the main factors that influence impulse buying, as there is no longer a need to make purchases only when money is available.

The opportunity subcategory was the most mentioned situational factors, indicating that the participants seem to prefer products with a limited or rare offer, buying only if it is not frequently seen. According to Cialdini (1993), the scarcity of a product is the belief that the products are more attractive, valuable and better when their availability is limited. When we are in a shop or shopping center, we tend to like and want more rare or unusual things because the idea of a possible loss plays a big role in decision-making, causing a fear that motivates us to act quickly (Cialdini, 1993). Thus, when informed that the product is the last or is limited, there is an increase in the perception of the product's value, and it becomes more desired (Cialdini, 1993). This way, the opportunity being the most mentioned subcategory among the situational ones indicates that this factor motivates impulse buying behavior.

As for the type of product, a study by Hor-Meyll and collaborators (2013) found that women tend to buy products related to aesthetics and clothing more impulsively. Another study showed that men tend to choose items related to entertainment (Bhakat \& Muruganantham, 2013) or purchases related to instrumental items (such as furniture, car or garden equipment) and leisure items (Beattie, Dittmar \& Friese, 1995). These cited studies differ from those carried out by Kollat and Willett (1967) and Narasimhan and by Neslin and Sen (1996), which show that most impulse purchase products concern food products. Considering the type of product, it was found that the category of products that most drives purchases is clothing. It happened possibly because the sample is made up mostly of female participants: and taking into account that women buy more products related to clothing, it is understandable that clothing was the largest subcategory of this factor.

The consumer's previous involvement with the product, in turn, translates into the state of motivation, excitement or interest in the item. Thus, the consumer's perception of the value, symbolism and quality of a product leads to an anticipated involvement and a greater probability of impulse buying. However, the low number of responses related to the perception of value, symbolism and quality may be associated with the fact that these three factors may not be as conscious and immediately accessed by the consumer when asked about what makes them buy on impulse.

Finally, the social value factor was the factor that obtained the least number of citations. Within the social value, in the external opinion, the reference groups seem to have great importance and influence when talking about buying behavior. Likewise, the presence of other people, such as the belonging groups, influence the purchase (Gonçalves, 2018). Likewise, consumption by status, which consists of buying certain products to reinforce status through purchase and the cultural factor, also influences impulse buying behavior (Kacen \& Lee, 2002) and being fashionable or follow trends. However, one reason why this was the least mentioned factor may be the occurrence of the bias of social desirability, making participants afraid to assume that they consume products to obtain status or to be in fashion, always having the stigma of wanting to be different and do not imitate others.

\section{FINAL CONSIDERATIONS}

Although not part of the main objective of this study, socio-demographic characteristics play a role in purchasing and consumption decisions, with variables such as gender (Beattie, Dittmar, \& Friese, 1995; Khawaja, 2018), age (Khawaja, 2018), culture (Kacen \& Lee, 2002), education and marital status (Akyuz, 2018) having an important influence on consumer impulsivity (Khawaja, 2018). Future studies may include these variables in their questions in order to obtain new qualitative evidence that will deepen the theme. 
There is also an important factor that, although it was not mentioned in the responses of the participants, is linked to personal factors that have a strong impact on the impulse buying behavior of consumers. These personal factors are related to consumers' personality and personal characteristics (Ambreen et al., 2018; Aquino, Natividade \& Lins, 2019). Psychological variables play an important role in the variation of impulse buying, as well as basic personality structures (Herabadi et al., 2009), and deserve to be investigated in future research.

Likewise, concerning individual characteristics, the impulse buying tendency is a predictor trait of this behavior (Beatty \& Ferrell, 1998). Consumers with a strong impulse buying tendency reflect a lasting willingness to act spontaneously in a specific consumption context (Blut, Grewal, Iyer $\&$ Xiao, 2019). Generally, they make an immediate and spontaneous purchase decision, stimulated by the environment, where strong feelings of buying products increase (Atulkar \& Kesari, 2017).

Finally, it should be noted that the results obtained do not mean that these are the main or only factors that make people get involved in purchases of this type. The characteristics of the sample should be considered as limitations of this study, and the social desirability that may be implicit in each answer, considering that the data obtained reflect only the free opinion of consumers when asked about what factors lead them to buy on impulse.

\section{References}

Agyeiwaa, A., Agyekum, C. K., \& Haifeng, H. (2015). Consumer perception of product quality. Microeconomics and Macroeconomics, 3(2), 25-29. doi: 10.5923/j.m2economics.20150302.01

Akram, U., Hashim, M., Hui, P., Khan, M. K., \& Saduzai, S. K. (2016). Impulsive buying: A qualitative investigation of the phenomenon. Proceedings of the Tenth International Conference on Management Science and Engineering Management, 1383-1399. doi: 10.1007/978-981-101837-4_112

Akyuz, A. (2018). Determinant factors influencing impulse buying behaviour of Turkish customers in supermarket setting. International Journal of Research in Business and Social Science, 7(1), 1-10. doi: 10.20525/ijrbs.v7i1.839

Alden, D. L., Batra, R., \& Steenkamp, J. B. E. M. (1999). Brand positioning through advertising in Asia, north America, and Europe: The role of global consumer culture. Journal of Marketing, 63(1), 75. doi: $10.2307 / 1252002$

Ambreen, G., Bushra, M. F., \& Zulfiqar, J. (2018). A comprehensive literature review of impulse buying behaviour. Journal of Advanced Research in Social and Behavioural Sciences, 11(1), 94-104.

Andrade, M. L., Assimos, B. M., Leite, R. S., Pinto, M. R. (2019). Conspicuous consumption and its relation to brand consciousness, status consumption and self-expression. Brazilian Business Review, 16(4), 350-368. doi: 10.15728/bbr.2019.16.4.3

Aquino, S. D., Natividade, J. C., \& Lins, S. (2019). Sua personalidade vai ao shopping? Relações entre personalidade e a compra por impulso. Psico, 50(4), 31905. doi: 10.15448/19808623.2019.4.31905

Assmar, E. M. L., Ferreira, M. C., \& Souto, S. O. (2002). 0 individualismo e o coletivismo como indicadores de cultura nacionais: Convergências e divergências teórico-metodológicas. Psicologia em Estudo, 7(1), 81-89. doi: 10.1590/S1413-73722002000100011.

Atulkar, S., \& Kesari, B. (2017). Impulse buying: A consumer trait prospective in context of central India. Global Business Review, 19(2), 1-17. doi: 10.1177/0972150917713546

Badgaiyan, A. J., \& Verma, A. (2015). Does urge to buy impulsively differ from impulsive buying behaviour? Assessing the impact of situational factors. Journal of Retailing and Consumer Services, 22, 145-157. doi: 10.1016/j.jretconser.2014.10.002

Bardin, L. (2011). Análise de conteúdo. São Paulo: Edições 70.

Beattie, J., Dittmar, H., \& Friese, S. (1995). Gender identity and material symbols: Objects and decision considerations in impulse purchases. Journal of Economic Psychology, 16(3), 491-511. doi: 10.1016/0167-4870(95)00023-H 
Beatty, S. E., \& Ferrell, M. E. (1998). Impulse buying: Modeling its precursors. Journal of Retailing, 74(2), 169-191. doi: 10.1016/S0022-4359(99)80092-X

Bhakat, R. S., \& Muruganantham, G. (2013). A review of impulse buying behaviour. International Journal of Marketing Studies, 5(3). doi: 10.5539/ijms.v5n3p149

Blut, M., Grewal, D., Iyer, G. R., \& Xiao, S. H. (2019). Impulse buying: A meta-analytic review. Journal of the Academy of Marketing Science. doi: 10.1007/s11747-019-00670-w

Campos, A. Q., \& Sousa, R. P. L. (2011). Tendências, marcas e consumo de moda: a eterna recriação de si. Modapalavra E-periódico, 4(8), 1-15.

Chen, T. (2008). Impulse purchase varied by products and marketing channels. Journal of International Management Studies, 3(1), 154-161.

Christopher, A. C., Marek, P., \& Troisi, J. D. (2006). Materialism and money spending disposition as predictors of economic and personality variables. North American Journal of Psychology, 8(3), 421- 436.

Cialdini, R. B. (1993). Scarcity: The rule of the few. In Cialdini, R. B. (1993). Influence: The Psychology of Persuasion, 178-205. Revised edition, New York, NY: Harper Collins e-books.

Coley, A. L. (2002). Affective and cognitive processes involved in impulse buying. (Tese de Mestrado). The University of Georgia.

Dellagnelo, E. H. L., \& Silva, R. C. (2005). Análise de conteúdo e sua aplicação em pesquisa na administração. In M. M. F. Vieira \& D. M. Zovain (Orgs.), Pesquisa qualitativa em administração: teoria e prática (pp. 97-118). São Paulo: FGV.

Dorfman, R., \& Steiner, P. (1954). Optimal advertising and optimal quality. American Economic Review, 44(5), 826-836. doi: 10.1007/978-3-642-51565-1_53

Eastman, J. K., Goldsmith, R. E., \& Flynn, L. R. (1999). Status consumption in consumer behaviour: Scale development and validation. Journal of Marketing Theory and Practice, 7(3), 41-52. doi: 10.1080/10696679.1999.11501839

Eberhardt, A., Lins, S., Poeschl, G. (2016). Identificando os factores de influência da compra por impulso em adolescentes portugueses. Análise Psicológica, 1(34), 147-163. doi: $10.14417 /$ ap. 920

Euromonitor International (2011). Make way for generation Z: Marketing to today's tweens and teens. Strategy Briefing.

Ferla, D. A. (2009). Estratégias de marca: Local, global ou glocal? IV Encontro de Estudos em Estatégia, $1-13$.

Ferreira, J. R. (2013). O Poder das marcas: A influência do brand equity \& brand experience na intenção de compra - Retail Approach. (Tese de Mestrado). Ipam, Marketing School. Porto.

Fisher, R. J., \& Rook, D. W. (1995). Normative influences on impulsive buying behavior. Journal of Consumer Research, 22(3), 305-313. doi: 10.1086/209452

Gonçalves, A. (2018). O impulso da pertença: a influência da identidade social na compra por impulso de jovens portugueses/as. (Tese de Mestrado). Faculdade de Psicologia e de Ciências da Educação. Porto.

Gutierrez, B. P. B. (2004). Determinants of planned and impulse buying: The case of the Philippines. Asia Pacific Management Review, 9(6), 1061-1078. doi: 10.6126/apmr.2004.9.6.03

Hall, A., \& Towers, N. (2017). Understanding how millennial shoppers decide what to buy. International Journal of Retail \& Distribution Management, 45(5), 498-517. doi: 10.1108/IJRDM11-2016-0206

Herabadi, A. G., Verplanken, B., \& van Knippenberg, A. (2009). Consumption experience of impulse buying in Indonesia: Emotional arousal and hedonistic considerations. Asian Journal of Social Psychology, 12(1), 20-31. doi: /10.1111/j.1467-839X.2008.01266.x

Herbig, P., \& Palumbo, F. (2000). The multicultural context of brand loyalty. European Journal of Innovation Management, 3(3), 116-125. doi: 10.1108/14601060010334876

Hirschman, E. C. (1980). Innovativeness, novelty seeking, and consumer creativity. Journal of consumer research, 7(3), 283-295. doi: 10.1086/208816 
Hor-Meyll, L. F., Livramento, M. N., \& Pessôa, L. A. G. de P. (2013). Valores que motivam mulheres de baixa renda a comprar produtos de beleza. RAM, Revista de Administração Mackenzie, 14(1), 4474. doi: 10.1590/S1678-69712013000100003

Hu, F., Li, H., \& Liu, Y. (2013). Website attributes in urging online impulse purchase: an empirical investigation on consumer perceptions. Decision Support Systems, 55 (3), 829-837. doi: 10.1016/j.dss.2013.04.001

Jung, K., Lantz, G., Loeb, S. G., \& Mai, N. T. T. (2003). An exploratory investigation into impulse buying behaviour in a transitional economy: A study of urban consumers in Vietnam. Journal of International Marketing, 11(2), 13-35. doi: 10.1509/jimk.11.2.13.20162

Kacen, J. J., \& Lee, J. A. (2002). The influence of culture on consumer impulsive buying behaviour. Journal of Consumer Psychology, 12(2), 163-176. doi: 10.1207/S15327663JCP1202_08

Kapferer, J. N., \& Laurent, G. (1985). Consume involvement profiles: A new and practical approach to consumer involvement. Journal of Marketing Research, 12(1), 41-53.

Khawaja, L. (2018). Factors influencing consumer buying behaviour toward impulse buying. The International Journal of Business \& Management, 6(6), 245-258.

Ko, H-C. (2018). Exploring the factors driving impulse buying tendency on advertisements of facebook: A social learning theory perspective. In Proceedings of the 10th International Conference on Education Technology and Computers, 245-249. doi: 10.1145/3290511.3290563

Kollat, D. T., \& Willett, R. P. (1967). Customer impulse purchasing behaviour. Journal of Marketing Research, 4(1), 21-31. doi: 10.1177/002224376700400102

Kumar, M., \& Noble, C.H. (2016). Beyond form and function: Why do consumers value product design? Journal Business Research, 69(2), 613-620. doi: 10.1016/j.jbusres.2015.05.017

Mozzato, A.R., \& Grzybovski, D. (2011). Análise de conteúdo como técnica de análise de dados qualitativos no campo da administração: potencial e desafios. Revista de Administração Contemporânea, 15(4), 731-747. doi:10.1590/S1415-65552011000400010

Narasimhan, C., Neslin, S. A., \& Sen, S. K. (1996). Promotional elasticities and category characteristics. Journal of Marketing, 60(2), 17-30. doi: 10.1177/002224299606000202

O'Cass, A., \& McEwen, H. (2004). Exploring consumer status and conspicuous consumption. Journal of Consumer Behaviour, 4(1), 25-39. doi: 10.1002/cb.155

Popadiuk, S. (1993). 0 processo de envolvimento na compra de um produto. Revista de Administração, 28(2), 83-91.

Raheem, A. R., \& Vishnu, P. (2013). Factors influencing impulse buying behavior. European Journal of Scientific Research, 100(3), 67-79. doi: http://www.europeanjournalofscientificresearch.com/issues/EJSR_100_3.html

Rook, D. W. (1987), The buying impulse. Journal of Consumer Research, 14 (2), 189-99. doi: $10.1086 / 209105$

Sato, A., \& Verplanken, B. (2011). The psychology of impulse buying: An integrative self-regulation approach. Journal of Consumer Policy, 34(2), 197-210. doi: 10.1007/s10603-011-9158-5.

Schiffman, L. G. (1972). Perceived risk in new product trial by elderly consumers. Journal of Marketing Research, 9(1), 106-108. doi: 10.1177/002224377200900125

Stern, H. (1962). The significance of impulse buying today. Journal of Marketing, 26(2), 59-62. doi: $10.2307 / 1248439$

Underwood, R. L. (2003). The communicative power of product packaging: Creating brand identity via lived and mediated experience. Journal of Marketing Theory and Practice, 11(1), 62-76. doi: $10.1080 / 10696679.2003 .11501933$

Yu, S., \& Lee, J. (2018). The effects of consumers' perceived values on intention to purchase upcycled products. Sustainability, 11(4), 1034. doi: 10.3390/su11041034 